\title{
Analysis of open source biotechnology in developing countries: An emerging framework for sustainable agriculture
}

\author{
Ademola A. Adenle ${ }^{\mathrm{a}, \mathrm{b}, *}$, Sulayman K. Sowe ${ }^{\mathrm{a}, \mathrm{b}}$, Govindan Parayil ${ }^{\mathrm{a}}$, Obijiofor Aginam ${ }^{\mathrm{c}}$ \\ a United Nations University, Institute of Advanced Studies (UNU-IAS), 6F International Organisations Centre, Pacifico Yokohama, 1-1-1 Minato Mirai, Nishi-ku, \\ 220-8502 Yokohama, Japan \\ ${ }^{\mathrm{b}}$ National Graduate Institute for Policy Studies (GRIPS), 7-22-1 Roppongi, Minato-ku, Tokyo 106-8677, Japan \\ ${ }^{\mathrm{c}}$ United Nations University, Institute for Sustainability and Peace (UNU-ISP), 5-53-70 Jingumae, Shibuya-ku, Tokyo 150-8925, Japan
}

\section{A R T I C L E I N F O}

\section{Article history:}

Received 7 June 2011

Received in revised form 22 July 2012

Accepted 31 July 2012

\section{Keywords:}

Agriculture

Biotechnology

Technology innovation

Sustainable development

Open source software

Intellectual property rights (IPRs)

Developing countries

\begin{abstract}
A B S T R A C T
Agricultural biotechnology (e.g. genetically modified (GM) crop technology) is rapidly growing and has immense potential to contribute to sustainable agriculture in developing countries. However, due to the privatization and increased intellectual property rights (IPRs) protection, many people in the developing world find it very difficult to access modern biotechnology research tools (e.g. genetic engineering, micro-propagation, mutation breeding etc.) to improve agricultural productivity. This paper reviews the existing open source literature and draws parallels between the open source paradigm and the effect of IPRs on agricultural biotechnology. Using standard qualitative research methodology and examining specific case studies and initiatives, an innovative Open Source Biotechnology Framework (OSBF) is proposed as part of the solution that could address the challenges with IPR and help bring about sustainable agriculture. This paper further examines the potential impacts, constraints, and adoption of open source for agricultural biotechnology. The paper concludes with a summary of issues arising from adopting the open source paradigm in agricultural biotechnology while proposing a way forward.
\end{abstract}

(c) 2012 Elsevier Ltd. All rights reserved.

\section{Introduction}

Sustainable agriculture is widely acknowledged as a fundamental component of any strategy to fight poverty and food security problems in developing countries. The World Bank estimates more than $86 \%$ of poor people living in developing countries rely on agriculture practices as the source of their livelihood [1]. Agricultural biotechnology

\footnotetext{
* Corresponding author. United Nations University, Institute of Advanced Studies (UNU-IAS), 6F International Organisations Centre, Pacifico Yokohama, 1-1-1 Minato Mirai, Nishi-ku, 220-8502 Yokohama, Japan. Tel.: +81 45221 2367; fax: +81 452212303 .

E-mail address: adenle@ias.unu.edu (A.A. Adenle).
}

has been recognised as a research tool that can potentially contribute to sustainable agriculture in developing countries. Recent reports have shown that agricultural biotechnology (especially genetically modified (GM) crop technology) has made a significant impact in terms of increased yields, increased income and improved quality of life in developing countries [2,3]. Crop varieties such as drought and herbicide-tolerant, insect and pest resistant traits have been developed using modern biotechnology, particularly genetic engineering. However, there is little or no access to this innovation that has great potential to improve agricultural productivity and sustainable development in developing countries.

One notable problem is obvious in the area of biotechnology research and development (R\&D). This problem is 
the increased intellectual property rights (IPRs) protection which can constitute both a problem and an opportunity for the adoption of agricultural biotechnology in developing countries. The GM crop technology is very expensive and investment oriented with a huge capital base market because biotechnology $R \& D$ is largely dominated by private-sector firms $[4,5]$. For example, in the US, revenue for the biotechnology industry increased from $\$ 8$ billion 1992 to $\$ 25$ billion in 2000 , an increase of over $300 \%$ during this time-period alone [4]. Multinationals placing strong IPRs on agricultural inventions including research tools have affected the development, adoption and diffusion of new innovation in developing countries. As a result, research tools that are needed for the development of subsistence crops are often not available. Some of the research tools used in modern biotechnology such as micro-propagation, marker-assisted breeding, mutation breeding and genetic engineering have produced different crop varieties in use today. These research tools are needed to overcome the inevitable crop production problems due to low yields, postharvest losses, drought, disease and insects in developing countries. Given the IPRs "logjam" that constrains these research tools, there is a need for innovative solutions to tackle food security problems.

The application of open source in software development led to the concept of applying open source in agricultural biotechnology [6]. Open source biotechnology is a method of creating genetically modified crops that does not infringe on patents held by large biotechnology companies. The technique would be made available free to others to use and improve as long as the improvements are also available free. Similar to open source software, the idea is to spur innovation. It is believed that open source will create opportunities through which life science inventions can be made available to the public and broad research communities by effectively opening up the IPRs "logjam" $[7,8]$. Open source as an alternative to proprietary technologies is gradually becoming popular in developing countries in the area of information and communication technology (ICT) [9]. Free accessibility and low cost are some of the characteristics that make open source software technologies an attractive proposition to poorer communities [10]. Developing countries are taking advantage of the inherent benefits of open source (e.g. availability of source code, ability to modify and customize the software, lower total cost of ownership, freedom from vendor lock-in, availability of community support, etc.) to solve practical problems in agriculture, health, environment and education to improve livelihood in the rural areas.

In order to use the open source approach, we must understand the role of IPRs with regards to the development of agricultural biotechnology and how open source can increase (or decrease) access to biotechnology innovation in developing countries. Therefore, we ask the following research questions in this investigation:

Q1. What role does IPRs play in limiting access to research tools such as modern biotechnology that has great potential to increase agricultural productivity in developing countries?
Q2. What are the relevant examples or case studies of the open source approach that can benefit sustainable agricultural development? Are there generalizable solutions than can be drawn from these cases?

Q3. Are there lessons to be learned from existing initiatives to facilitate access and promote open source approach for biotechnology R\&D?

The aim of this paper is to provide answers to these questions by investigating the role of open source biotechnology in sustainable agricultural development.

\subsection{Research methodology}

In social and physical sciences research, relying on and integrating data from multiple sources has long been recognized as a standard practice. Triangulation or crossexamination is often used to indicate this research methodology [11]. Triangulation increases the reliability of the data by allowing the researcher to make inferences and value judgement by comparing and contrasting information in one data set against another. In the context of data collection, triangulation serves to corroborate the data gathered from various sources. Furthermore, Denzin (2006) [12] distinguished between four types of triangulation research methods, and pointed out that methodological triangulation (such as the one employed in this research) involves using multiple choices to gather data, such as documents or review of the literatures, observations of initiatives that can add value to what is being studied [11,12].

Given the paucity of empirical data linking open source and agricultural biotechnology, especially in the context of developing countries, qualitative methodological approaches are the most appropriate for synthesizing evidence from various sources, increasing confidence in the interpretation of research results, and enabling the results to build or propose frameworks (such as the Open Source Biotechnology Framework-OSBF) which may help others to undertake research in this area.

In our first data source, the literature and best practices review provided an overview of this field of study but also may increase our understanding of the sustainable aspects of agricultural practices in developing countries. The second data source, the case studies, helped us to find out why open source can be a valuable tool in overcoming the IPRs logjam, facilitating access to information, and mitigating risks. The main reason for using case studies as research instruments is grounded in the argument by Yin (2003, p111) [11], that a case study design should be considered when "the focus of the study is to answer how and why questions" and when the researcher wants to "cover contextual conditions" which are believed to be relevant to the phenomenon (agricultural biotechnology) studied. Thus, a case study approach was chosen for this research. In the third data source, we contrast four prominent initiatives that promote open access to agricultural and health biotechnology innovations. 
The rest of the paper is structured as follows. Section 2 introduces background and work related to our research, and describes the principles of open source and how the concept of open source software is similar to traditional farming practices of free sharing and exchanging of seed. Section 3 discusses the implications of IPRs and demonstrates relevant examples of tools used by the IPRs system in agricultural biotechnology. Section 4 examines potential benefits and the impact of open source on agricultural development. This section also demonstrates examples through case studies and initiatives promoting agricultural biotechnology innovation. Section 5 examines the constraints associated with the adoption of open source biotechnology and proposes an Open Source Biotechnology Framework (OSBF) with policy implication towards advancing agricultural development. Finally, the paper concludes with a summary of critical issues for open source biotechnology development.

\section{Background}

The term open source was first used in free software development [13]. Free open source software (FOSS) uses free software and open source which is licenced to use, copy, modify, redistribute and gives the opportunity to increase the value of software or technology to a desired taste or for different purposes with the full access to the source code $[6,14]$. For example, the free software foundation (FSF) uses free software licences and the open source initiative (OSI) uses open source licences. Other FOSS movements include the FOSS Bazaar, ${ }^{4}$ Creative Commons ${ }^{5}$ and the Debian Linux Community $[6,15,16]$. The FOSS projects have been remarkably successful with many open source programs available and most recognized among them include Linux, Apache and Mozilla. Open source technology can be made available under a copyleft ${ }^{6}$ licence that prevents an individual or any organisation modifying and reproducing the technology for proprietary purposes since the initial access to the technology is open and free, and must be modified or reproduced upon initial agreement [17]. The idea of the copyleft licence is to ensure that everyone has free access to the innovations without further restrictions.

However, enhanced value of the technology can still be converted into economic benefit just as in the case of proprietary technology, but at the same time it must be freely offered to the public [18]. The concept of open source is, however, a matter of liberty not necessarily production cost as there are typically no costs evaluated toward labor even though the process is labor intensive.

\footnotetext{
4 FOSS Bazaar is an open community of technology and industry leaders that collaborate on how to accelerate the adoption of free and open source software in the enterprise as well as focussing on best practices, education and tools (https://fossbazaar.org/).

${ }^{5}$ Creative commons recommends and uses free and open source software licences (General Public Licence-GNU) for software development (http://creativecommons.org/software).

${ }^{6}$ Copyleft is a word used to describe the practice of using copyright law that allows distributing copies and modified versions of work and granting the same right preserved in modified version of the work.
}

Therefore, one should think of "free speech", not "free beer" when understanding open source software [19]. The increase in the value of investing in the time and labor for open source technology is in downstream cost savings. In science, this can be in the form of a research tool that was reproduced and improved leading to a high quality product through open source development. This would make the research tool available to the community at no cost, increasing the opportunity for more innovation through broader access.

Over the past decade, the awareness of open source is increasingly growing worldwide. The open source principles hold substantial promise for developing countries particularly in the area of biotechnology (e.g. agriculture, health). Due to the mode of operation and the benefits associated with open source, different initiatives are being deployed across different fields, promoting the use of open source for the benefit of the society. This idea has led to numerous innovations in terms of operating systems and products. The free open source operating system (GNU/ Linux Software) as first initiated by Linus Torvalds $[16,20]$ has made a significant impact in promoting open-source development and many initiatives have followed this example. Some of the initiatives using open-source and 'copyleft' approach for their research tools include: The International HapMap project for mapping haplotypes of human genomes [8], computational drug discovery and developments for treating tropical diseases by Tropical Disease Initiative [21], biological R\&D by the Open Bioinformatics Foundation [22], advanced genetics for improving agriculture and sharing biological innovations in poor communities by Biological Innovation for Open Society [7] which is founded by Centre for the Application of Molecular Biology to International Agriculture [23] called CAMBIA BiOS Initiative.

Agricultural innovations are widely known as the key driving force for rural development in developing countries. And farmers play a vital role in the development process of innovations but are faced with problems of insects and pests, low income, small yield products, lack of communication and other technological problems in developing countries. Some of these problems are partly due to multiple intellectual property claims on key inputs and tools used in agricultural biotechnologies. Because of these factors, and the need for innovation to be more affordable and become more decentralized, the open source development presents an alternative distributive model in technological development for agricultural innovation.

Moreover it is possible that some version of open source software may be directly relevant to agricultural R\&D. An example was given by some authors in the case of the seed industry relating the event to computer software in the 1970s [24,25]. Douthwaite and Srinivas (2002) [24,25] observed that it was a traditional practice for computer programmers to freely exchange code among themselves which was similar to farmers that shared seeds freely with others for growing, improving, saving and reproducing crops. These days, a very different model has emerged where private companies in software and agriculture lead innovation which limits this older practice of free sharing. 
As discussed in this section above, an open source mechanism called copyleft was developed so that any innovation resulting from the open source approach would not be protected or stopped from copying or modifying either by the original licensor or his licensees under open source licence [26]. The same copyleft approach will be applied in agriculture where innovations are developed and allowed to be shared freely among the innovators as bound by the rules and agreement of open source licence for further improvements and distributions without any obstacles. Through this method, open source biotechnology can play a significant role in future agricultural development especially in seed industries that have been dominated by multinationals restricting access to the distribution of seeds through the intellectual property rights (IPRs) system. Based on these practices and the initiatives described above, we define open source biotechnology in this investigation as the development and maintenance of agricultural practices and research tools that allow both producers (e.g. companies) and consumers (e.g. farmers) to actively participate in the development process and freely reveal and share their innovations.

\section{The implications of IPRs for agricultural biotechnology}

Intellectual property rights (IPRs) are a set of laws that confer exclusive rights on inventors or products of inventors for a given period of time [27]. The role of IPRs became prominent in the protection of plant varieties in the second half of 20th century [28]. The assignment of IPRs to plant protection first took place in United States (US). When the vegetable propagated plant was patented in 1930. Prior to this event, traditional farming was mainly based on freely exchanging, saving, collecting and replanting seeds among the farmers. But the introduction of IPRs, particularly for agricultural research tools and databases through different patenting systems has led to the expression of concerns among different communities such as farmers, universities, plant scientists, industries, and governments particularly in developing countries. The concerns are based on agricultural innovations being hindered through introduction of IPRs that interferes with traditional farming practices. This section will focus on the implication of IPRs for agricultural biotechnology with relevant examples, while examining the role of patents, terminator technology and freedom to operate innovative technology.

\subsection{The role of the patent in agricultural biotechnology}

The existing intellectual property rights (IPRs) relevant to agricultural biotechnology are complex [29]. Most of the international agreements focus on different aspects of agricultural IPRs that are governed by different sets of rules, guidelines and policies. For example, the International Union for the Protection of New varieties of Plants (UPOV) focuses on protecting the right of seed producers (e.g. commercial plant breeders). The Convention on Biological Diversity (CBD) focusses on protecting the rights of farmers using landraces. The Traded-Related Aspects of Intellectual Property Rights (TRIPS Agreement) of World Trade
Organisations (WTOs) works specifically on strengthening the rights of inventors [30].

However, when these organisations are expected to work together towards a common goal, international changes in the IPRs system sometimes cause failure to deliver. For example, UPOV was established by six European nations in 1961. And it was subsequently revised in 1972, 1978 and 1991. The emergence of UPOV in 1961 triggered approval and passage of the Plant Variety Protection Act in US in 1970 [31]. The difference in policy and guidelines between North America and Europe which led to the change [32], helped prevent access to informal exchange, as well as farmers saving and replanting of seeds through the enforcement of law. This is in sharp contrast to the original UPOV that allowed breeders to exchange or sell their seeds by member countries [33].

At the same time, the current international environment for IPRs adds to the complexity of the IPRs regime because there are multiple entities representing different interests and processes. The lack of coherent international agreements has created loopholes for agricultural IPRs, particularly in the area that relates to agricultural biotechnology, therefore creating more opportunities for multinationals to exploit loopholes in legal agreements with developing countries [29]. For example, CBD was criticised for not recognising the IPRs agreement within the context of TRIPS. In fact the TRIPS agreement undermines the role of $\mathrm{CBD}$ in conserving biodiversity and managing genetic resources. Typically, law is being enforced through collaboration between national and international institutions on a global scale. Furthermore, the developing countries are under obligation in line with the TRIPS agreement for the protection of plant varieties either by patent or by other means of the IPRs system [29]. This agreement was done without necessarily considering its beneficial effects on consumers or producers and its possible impact on food security in developing countries. However, the UN Food and Agriculture Organisation (FAO) played an important role in reaching a positive agreement for developing countries in the International Treaty on Plant Genetic Resources for Food and Agriculture [34].

The issue of IPRs became even more challenging when two independent events took place in the US the same year. These events were pivotal for innovation in life sciences: the legislative approval and implementation of the BayhDole established Act of 1980, and Supreme Court decision in favour of patent protection on genetically modified organisms in the landmark Diamond v. Chakrabarty in 1980 [35]. After this remarkable development, a series of events followed, in the US and across Europe where large investments were made in agricultural technology in the private sector in collaboration with the universities. Modern IPRs regimes (patent regimes) have been heavily criticised by some due to non-disclosure of many innovations that can benefit the public. The US is arguably the largest world patent portfolio. The total number of patents analysed between 2002 and 2009 was 7469 [5]. Of these figures, the US accounts for 5, 690 filed under the US Patent and Trademark Office (USPTO) while 1779 were filled under the European Patent Office (EPO). The annual trend in crop biotechnology patents is shown in Fig. 1. The patents 


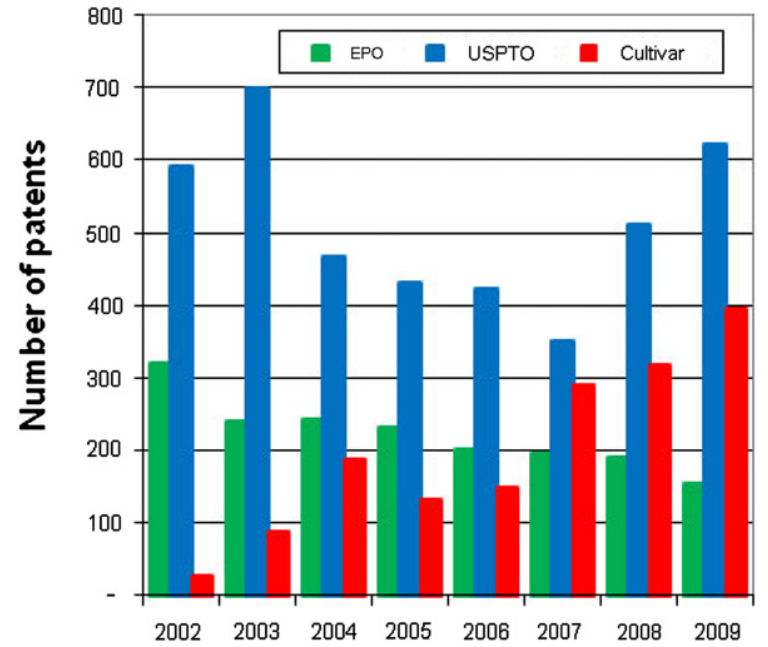

Fig. 1. Annual trends in patents of crop biotechnology between 2002 and 2009. Source: (Frisio et al., 2010) [5].

related to the cultivars were only patentable at the USPTO which suggests that the US controls agro-biotech markets due to the large R\&D investments [5].

The private sector is mostly involved in biotech industries and makes extensive use of IPRs in form of patents [5,36-39]. Multinationals such as Monsanto, DuPont, Syngenta and Bayer are famous for acquiring large number of patents with more than $70 \%$ of the patents in agricultural biotechnology in between 2002 and 2009 [5]. About $80 \%$ of biotech patents under the cultivars category can be attributed to three of six integrated major multinational companies (Monsanto, DuPont and Syngenta). According to Jefferson [37], Monsanto alone has a patent application for over 460,000 genes which is more than 10 times the number in any plant species. Some of these biotech companies have large markets in developed countries with a strong IPRs on cash crops (corn, cotton, and soybean) through patent. The lack of free access to innovative tools was largely responsible for the slow development of genetically modified (GM) crops with herbicide tolerance traits according to American Cyanamid [38]. In addition, multinationals mainly concentrate on crops of primary interest which will result in the largest financial benefit derived from cultivating these crops, therefore neglecting the innovation needed to develop "orphan crops"7 that are simple and cost effective for poorer countries. This is consistent with the argument raised by Parayil (2003) [39] that certain crops are developed to increase shareholder value for private companies as opposed to solving the problems of hunger and deprivation in developing countries.

The issue of "patent thicket" arises when there are numerous negotiations involving high transaction cost and uncertainty with different patent holders [40]. The

\footnotetext{
7 Orphan crops are a diverse set of minor crops such as millet, yam, cassava, cowpea, sorghum grown by poor farmers. These crops are not traded around the world and also receive little or no attention from research networks but play an important role in regional food security.
}

resulting transaction cost limits innovations. According to Isaac and Walter (2004) [41], economists refer to the need for such negotiations under the general rubric of "transactions costs". The most famous example is "Golden Rice" which has experienced a lot of delays due to a patent thicket of about 40 contractual obligations that initially caused the Golden Rice project setback [40]. Golden Rice was a biotech innovation that could potentially solve vitamin-A deficiency problems in developing countries where millions of young children were dying of malnutrition. It became a "bone of contention" among more than two dozen biotech companies claiming the patents. Golden Rice saga demonstrated that multiple owners holding overlapping and fragmented IPRs to different components of a large innovation can be a problem for developing and disseminating innovation. Academic researchers are affected when there is high transaction cost on a wide range of innovations. Their research becomes more difficult when there is uncertainty as to whether they might infringe company patents, sometimes regarded as "research exemptions" without seeking licences [42].

This has led to questions of whether enforcement of patent rights stand in the way of basic research in universities. Genetech argued that open science was being encouraged without enforcing patent rights on research tools [43]. This is in contrast to arguments presented by Eisenberg which was based on high transaction cost for acquiring proprietary research tools that involved many different institutions [44]. Two cases cited by Eisenberg include patent research tools such as rDNA and polymerase chain reaction (PCR) of Cohen Boyer and Hoffman La Roche respectively. Eisenberg (2002) [44] further argues that strong IPRs on research tools lead to reduced innovations and underused knowledge that creates rights of exclusion (anti-common) by IPRs holders. An example of the expressed sequence tag (EST) was given, a situation where some groups attempted to patent EST but abandoned this due to resistance from other competitors. This view suggests that once there is patent lock on innovative tools it creates a logjam in health and agriculture, development worldwide [37].

While Eisenberg and others presented some evidence with regards to the argument that patents create less innovation and adversely affect R\&D [35,44], some literature has argued that patents enable collaboration and facilitate negotiations between research tool users and producers leading to development [45-47].

\subsection{What role can 'terminator' technology play?}

One of the primary purposes of intellectual property rights (IPRs) in biotech industries is to gain profits through the application of patenting, temporarily allowing companies to have a monopoly on certain innovative technologies, particularly in agricultural biotechnology. This is demonstrated by the revenue generation trajectory of biotech firms where plant patents that are held by private firms situated in developed countries generate revenue from the poorest for multinationals in the wealthiest countries $[39,48]$. With the development of new plant varieties by these companies, a different strategy is devised where IPRs cannot effectively serve their intended purpose. The use of 
terminator technology has the potential to circumvent this problem. The word 'terminator' was coined by activist groups in an attempt to ban the use of sterile seed technology [49]. The original name is called Genetic Use Restriction Technologies (GURTs). GURTs were granted US patent $(5,723,765)$ in 1998 to joint partnership between U.S. Department of Agriculture (USDA) and Delta \& Pine Land Company (the U.S. biggest company supplier of cotton) for the two types: trait-specific (T-GURT) and variety-level (VGURT) [50]. While T-GURT is designed for GM trait-specific (e.g. disease resistance), V-GURT is designed for GM crop varieties through seed sterility [51,52].

The terminator technology is mostly targeted at developing countries where IPRs are non-existent and terminator technology may not have much effect on developed nations as other technologies can be used to unravel and relocate innovative characteristics for plant breeding [53]. The idea of introducing terminator technology is not only to protect IPRs and stimulate private R\&D but to prevent the flow of unwanted genes from genetically modified (GM) crops, and to help solve plant-back problems in GM crops [52,54]. According to Eaton et al., (2002) [52], the implementation of terminator technology can potentially lead to a reduced atmosphere for sharing genetic resources through increased IPRs protection, particularly among competing companies and institutions. In developing countries, poor farmers may not be able to afford GURT seeds from suppliers every year and also may limit their ability of saving and exchanging seed practices. And Monsanto may sue farmers that save and reuse their seeds. For example, an infringement suit was brought against a farmer that saved 1500 bushels of Bt soybean seeds from his field enough to grow 1500 acres another year [55]. This approach may discourage poor farmers from buying patented seeds. Moreover, traditional crops may suffer reduction in viable seed production from sterile GURT seed technology due to pollen transfer [56,57].

Although, it may be possible that the so called T-GURT form of what is referred to as terminator technology would serve a good purpose in terms of disease resistance [58], saving and replanting the seeds (excluding transgenic traits) but farmers will have to pay for activating chemicals each year [59]. Given little or no detailed application of V-GURT in the literature [60], more evidence-based scientific research will need to be done, but the opportunity may not exist in the future as the terminator technology kind of approach in agricultural biotechnology is widely opposed. For example, as a result of wide-spread criticism of terminator technology (V-GURT, in particular), the application of V-GURTs for different varieties was disqualified in India [51] and was rejected by the Rockefeller Foundation [61] and by the Consultative Group on International Agricultural Research (CGIAR) [62]. Given this opposition, it may be difficult for GURT technology to replace IPR in developing countries.

\subsection{Freedom to operate innovative bio-technology}

Open source has become an important mechanism to deliver free access in a global market for public goods such as innovative bio-technology. When monopoly rights are conferred on innovation, it narrows the field of innovation, particularly in the areas critical for the public goods (such as genetic resources for agriculture). The problem is that government funding for $R \& D$ is far less than private sector funding meaning that the profit motive becomes a priority. While this drives technological innovation and economic development in many instances, in some instances it can inhibit the diffusion of innovation. For example, when a company or institution invents a technology, a patent is usually filed so that such invented technology is protected from free use. In most cases, the company prevents exclusive use of technology to regain any investment made on the invention for about 20 years when the patent would have run out [63]. In contrast, open source technology is free and company owned technology is protected. However, while some successes have been recorded in open source projects, particularly in software development, many open source projects have experienced little or no development due to a lack of momentum behind them $[64,65]$. Given this challenge, efforts should be increased for the involvement of country government, private sector and international organizations to facilitate and encourage freedom to innovate where access is limited to biotechnology R\&D, particularly in developing countries.

The researchers at the universities or academic institutions find it difficult to use research tools that could lead to more innovations due to associated risks, particularly in the light of patented technologies, while advancing their research work. Some literature evidence suggests that researchers are experiencing difficulty, delay and redirecting of research due to the high cost and problem of accessing permission to patented technology that can benefit research programs [66,67]. Even though, this kind of problem often happens in developed countries, without doubt, it becomes a spill-over problem when the technologies are transferred to developing countries [68]. According to Hoekman et al., (2004) [68], the improvement that occurs at a rapid rate may not be located in another industry without the policies for the productivity improvement that depend on a country's own R\&D. When this problem occurs, freedom to operate becomes a difficulty due to a lack of easy and quick access to material held by others. Again, the cost of freedom to operate may be too high for public institutions to afford [69]. Additionally, the use of IPRs as constraining innovation is seen as a problem in universities and in developing countries. Most significantly it can be a serious threat to the supply of food due to the problem of access to IPRs as expressed by the international research and donor communities [70].

\section{Potential benefits and impacts of open source for agriculture and biotechnology}

The role of information and communication technology (ICT) in improving the quality of life in rural areas of developing countries is fast gaining recognition [71]. The benefits of open source innovations are common in many areas of ICT for educational, social and economic activities around the world. Now, open source has started to benefit agricultural practices in developing countries for improving agricultural productivity and providing better 
communications within farming communities that connects farmers to the rest of the world.

Table 1 demonstrates specific cases of open source for agricultural development in developing countries. Examples of case studies such as Agribazzar, OSCAR (Simple Computer for Agriculture in Rural), SOPAC (South Pacific Applied Geoscience) and e-Transform Agriculture are established by the country governments in partnership with developed countries and international organizations to enhance sustainable agricultural development in developing countries. This kind of open source innovation will provide opportunities for farmers to increase their knowledge on best farming methods, provide relevant information on agricultural inputs (e.g. fertilizer and seed), weather, storage and other farming activities, and widen their markets and gain new customers without internet connection, particularly in the rural areas $[10,72,73]$.

Apart from the examples demonstrated in the Table 1, there are several other initiatives being implemented through Open Mobile Consortium in developing countries particularly in Africa to facilitate access to information between non-governmental organisations (NGOs) and small farmers in the rural communities. For example, the United Nations Children's Fund (UNICEF) Innovation has created an open source platform called Rapid SMS to monitor food distribution in Ethiopia and to assist in improving process of tracking the nutritional trends of Malawian children [73]. Frontline SMS is another open source platform that provides free access to software that is being used mostly in developing world in the area of agricultural development [74]. The biggest impact of Frontline SMS has been recorded in Philippines, Nigeria,
India, Malawi, Pakistan and Kenya. For example, in Kenya, Frontline SMS facilitates and increases access to sales and deliveries as well as providing more accurate price, quality, and quantity information among small farmers and medium-size retailers. The ICT sector unit of World Bank group has described several mobile applications for agriculture and rural development (m-ARD) that can be made available via open source in developing countries [75]. For example, m-ARD applications are under detailed case studies for agriculture markets and extension services and these applications are active in many developing countries including India, China, Philippine, Colombia, Argentina, Uruguay, Tanzania, Uganda and Kenya. Although many of these mobile applications are pilot studies they still hold promise for advancing future agricultural production and enhancing food security in developing countries.

While the impact of Frontline SMS is growing in health and agricultural development $[74,76]$, effort is required in the area of ICT education which is the key to successful adoption. Qiang et al., (2011) [75] emphasised that the private sector, the public sector and donors must increase their efforts by improving the infrastructure, training young professionals and opening up access to publicly available data to facilitate development of mobile application.

Biotechnology is another field where open source has great potential to contribute to agricultural development. Open source biotechnology may be key to knowledge and innovation for agricultural development, and part of the solution to the increasing population problem in developing countries. Given the patent impediments on new agricultural innovations, different initiatives are emerging

Table 1

Open source for agricultural development case studies.

\begin{tabular}{|c|c|c|c|c|}
\hline Case study & Summary of activities & Consortium/partners & $\begin{array}{l}\text { Open source rational and } \\
\text { benefits }\end{array}$ & References \\
\hline AgriBazaar & $\begin{array}{l}\text { AgriBazaar is an internet based agric- } \\
\text { related trading for producers and } \\
\text { suppliers. It provides real-time market } \\
\text { information and prices of farm } \\
\text { produce. }\end{array}$ & $\begin{array}{l}\text { Agriculture Department of } \\
\text { Malaysia and the Malaysian } \\
\text { Institute of Microelectronic } \\
\text { Systems }\end{array}$ & $\begin{array}{l}\text { Free accessibility, ability } \\
\text { to customize the and } \\
\text { translate the software } \\
\text { interface (GUI) into local } \\
\text { languages, low maintenance } \\
\text { and cost effectiveness }\end{array}$ & [10] \\
\hline $\begin{array}{l}\text { OSCAR - simple computer } \\
\text { for agriculture in rural } \\
\text { areas }\end{array}$ & $\begin{array}{l}\text { For farming community of the Indo- } \\
\text { Gangetic Plains (IGP) using open } \\
\text { source software applications for } \\
\text { identifying/controlling weed in rice } \\
\text { and wheat crop system that suit } \\
\text { local languages and cultural practices } \\
\text { in different regions. }\end{array}$ & $\begin{array}{l}\text { Asia-Europe collaboration. } \\
\text { French institute of Pondicherry } \\
\text { (IFP) lead project. }\end{array}$ & $\begin{array}{l}\text { To assist decision making } \\
\text { on farm-level concerns in } \\
\text { agriculture with relevance } \\
\text { among farmers, extension } \\
\text { officers, scientists and } \\
\text { students }\end{array}$ & [77] \\
\hline $\begin{array}{l}\text { SOPAC-South Pacific } \\
\text { applied geoscience }\end{array}$ & $\begin{array}{l}\text { Aimed to reduce vulnerability using } \\
\text { GeoCMS application software to help } \\
\text { collect and publish geographic data } \\
\text { for access and sharing over the } \\
\text { Internet. }\end{array}$ & $\begin{array}{l}\text { European funded project in } \\
\text { collaboration with } 14 \text { African, } \\
\text { Caribbean and Pacific Group of } \\
\text { States (ACP) }\end{array}$ & $\begin{array}{l}\text { To facilitate sharing of } \\
\text { information and awareness } \\
\text { promotion on hazard } \\
\text { mitigation and risk } \\
\text { assessment, water resources } \\
\text { supply and agricultural } \\
\text { practices }\end{array}$ & [10] \\
\hline e-Transform Africa & $\begin{array}{l}\text { mAgri programme is an example of } \\
\text { eAgriculture to read, capture and } \\
\text { store data through mobile } \\
\text { technology being promoted in } \\
\text { African countries }\end{array}$ & $\begin{array}{l}\text { A partnership between the World } \\
\text { Bank and the African Development } \\
\text { Bank (AfDB), supported by the } \\
\text { African Union (AU) }\end{array}$ & $\begin{array}{l}\text { To facilitate multi-stakeholder } \\
\text { partnerships and services } \\
\text { among farmers, extension } \\
\text { officers, scientists and other } \\
\text { organisations for free } \\
\text { agriculture knowledge } \\
\text { sharing. }\end{array}$ & {$[78]$} \\
\hline
\end{tabular}


through open source development to facilitate access to modern agricultural biotechnology. Table 2 shows example of initiatives that are promoting open access to agricultural biotechnology with the exception of the International HapMap project promoting open access to health biotechnology. The fundamental rationale for the open source movement is to ensure the development, distribution and adoption of agricultural biotechnology that will benefit researchers and ultimately small-holder farmers in developing countries. The same concept is adopted by the International HapMap project for health biotechnology to facilitate open access to the development of diagnostic tools between developed and developing countries [79], as described in the Table 2.

Efforts by the CAMBIA BiOS initiative (Table 2) are not just about the campaign or creating awareness, but they demonstrate practical examples of donating free technologies through open source licencing. Of all the initiatives, the BiOS initiative under the leadership of Richard Jefferson is arguably the most useful for developing a framework for agriculture and has been at the forefront of promoting open source for sharing biological innovation [83]. For example, the GUS reporter system arguably remains the most widely used staining technique in plant science with over 4000 literature citations. Two different academic institutions have benefited from using open source research tools for carrying out experimental research in agriculture [84]. The scientists at Cornell University in collaboration with a Hawaiian Papaya Growers Co-operative (made up of a small group of farmers) used CAMBIA open source research tools to find a solution to a virus problem in papayas. The second example of use took place at Huazhong University where more than 20,000 unique lines were created by Zhang Qifa, a leading Chinese scientist in plant biotechnology.

However, the Public Intellectual Property Resource for Agriculture (PIPRA) can be distinguished from opensource as they have different approaches for sharing

Table 2

Initiatives promoting open access to agricultural and health biotechnology innovation. Source: $[8,79-82]$.

Initiative

CAMBIA

PIPRA

AATF

International HapMap project
Major areas of activity

The Centre for the Application of Molecular Biology to International Agriculture (CAMBIA) was first formulated in mid-1980s by Richard Jefferson but developed into an integrated, full-text database of patents in the agricultural sciences that was funded by the Rockefeller Foundation in 1999. CAMBIA makes biotechnological research tools widely available through BiOS (Biological open source) initiative, Patent Lens database and BioForge. The BiOS Framework creates, validates and promulgates licencing tools, along with the norms and new business models to make use of strategies for "open source" creation, improvement, and sharing of enabling technology without impediment by patents and licences for the greater good of the public. BiOS initiative has led to emergence of biotechnological innovation such as $\beta$-glucuronidase (GUS) reporter gene system and Rhizobium strains (TransBacter system). GUS reporter gene system has been a mainstay of plant biotech research that led to the first release of transgenic potatoes in 1987. The Patent Lens is a platform to focus, understand, and investigate the patent rights and to inform practitioners and policy-makers. It is a free full text searchable database for intellectual property informatics and analysis containing over 1.6 million patents in the life sciences. BioForge is an online interface where enabling technologies is made available via creating and distributing key "pump-priming". Creating an innovation where IPR or patent restricts free access to diagnostic technology can be a useful tool to solve farming problems under BioForge open-source initiative. Since its establishment, efforts have been geared towards a strong campaign to provide communicative systems that allow dispersed individuals to participate and benefit from decentralised innovative research.

The Public Intellectual Property Resource for Agriculture (PIPRA) involves a group of non-profit institutions from more than 15 countries around the world with focus on intellectual property issue (e.g. patent) by providing free access to patented technology, particularly agricultural biotechnology under a set of shared principles. PIPRA membership is open to any university, public agency, or non-profit research institution actively engaged in research and development, but subject to supporting PIPRA's mission and agreeing to the terms laid out in the PIPRA Memorandum of Understanding (MOU). A concerted effort has been made to develop a database of 6600 agricultural patents involving 45 different countries. PIPRA's goal is to ensure farmers, researchers and other organizations are provided with right resource for clarity and analysis of patented technology through effective implementations. PIPRA acts as a resource for technology transfer programs, and for scientists that work in the public sector, to facilitate the transfer and adoption of their technologies. Part of their goals is to mobilize and encourage innovative technologies among various institutions for the development and distribution of subsistence crops based on humanitarian purposes in developing countries.

The African Agricultural Technology Foundation (AATF) is an Africa-based non profit organisation that negotiates and facilitates for the delivery and access of appropriate proprietary agricultural technologies to smallholder farmers in Sub-Saharan Africa. AATF engages in public/private partnerships to facilitate sharing and transfer of technology and research products that will benefit African resource-poor farmers without access constraint. For example AATF obtained a royalty-free Monsanto GM technology, a Bacillus thuringiensis $(B t)$ gene (cry-1Ab) and sublicensed it to the Australian Commonwealth Scientific and Industrial Research Organisation (CSIRO) and Nigerian-based International Institute for Tropical for Agriculture (IITA) for the development of pod borer resistant cowpea crop. When the GM cowpea is ready for use in future, the biotech product will be made available through the commercialization and public institution for humanitarian use.

The international HapMap project was originally launched in October 2002 to create genome wide database of common human sequence variation from population with ancestry parts of Africa, Asia and Europe. The goal of this project is to store and share data, and make the information freely available in the public domain. The consortium is composed of scientists, funding agencies, public and private organisations from six countries; the United States, Japan, Canada, China, Nigeria, and the United Kingdom. The aim is to enable researchers to find genes that affect health, disease and responses to medications that will lead to development of diagnostic tools. 
innovations. PIPRA offers services in terms of collaboration with institutional members on intellectual property policy analysis, biotechnology resources, and commercialization strategy to improve and develop shared technology packages $[81,85]$. In open source, service is focused on cumulative improvement which requires downstream transfer of the open-sourced materials under a copyleft style "grant back mechanism" (licensees must agree to share back and allow the right to re-use improvement made on research tools under open-source licence) [86]. While both initiatives differ in a way, they serve the research community well and achieve their purpose of encouraging and sharing innovation by creating more free access to research tools that can benefit various institutions across different countries.

While the African Agricultural Technology Foundation (AATF) and the International HapMap project are under different pilot phases, there is a need to encourage a wide range of stakeholders in private and public sector to increase their commitment so as to make it a reliable and effective open source biotechnology operating system.

\section{Challenges in open source biotechnology adoption and the proposed solutions}

\subsection{Constraints in adopting open source biotechnology}

As demonstrated above, open source biotechnology has potential to benefit human development, but there are fundamental challenges that must be properly addressed to ensure that open source delivers on its potential. Even though challenges will vary from country to country, most challenges will more likely be faced in developing countries largely due to the high level of poverty, political instability, economic instability and limited resources. Moreover, the challenge of open source adoption will remain a global problem as long as the majority of the world population has little or no access to it. The challenge in using open source biotechnology will not only be in the area of agriculture practices but in every aspect of biological innovation.

Introducing open source biotechnology in developing countries will require a considerable amount of training. Where there is a fair amount of knowledge of ICT, some amount of retraining may be required. For example, AgriBazaar (Table 1), using FOSS tools in Malaysia were difficult due to the lack of familiarity among software developers. Some of the engineers are used to proprietary software products, and similarly it will take time to adjust to a new product in agricultural biotechnology. Also, the interoperability problems may cause reluctance among the users where organisations need to change to open source [10]. In many places in developing countries, particularly in Africa, the lack of basic infrastructure such as communications and electricity may delay the application or adoption of open source biotechnology. For example, high-bandwidth Internet access is lacking in universities and research institutions coupled with an erratic supply of power. This can limit the ability to participate in open source projects. Furthermore, factors such as a shortage of IT professionals and the absence of IT industries in developing countries can delay the open source development. Each of these cases requires enormous finances for training and retraining processes, and constructing new infrastructure for IT purposes.

The challenge of IPRs is arguably the most complex due to the high cost involved. In the case of resource-poor farmers, an open source consortium that requires IPRs to protect farmer's resources can be very expensive to obtain and maintain, and this may be a big burden to farmers that have limited financial resources [87]. In spite of the fact that the general open source licence policy is based on the promise to keep source code free and allow free access to copyright-protected aspect of the code, challenges still remain in open source biotechnology. There are challenges of the translation of open source software model to biotechnology due to different characteristics governing the patent versus the copyright laws. To achieve protected common access (allow users to access) in open source, copyright as the dominant IPRs licence is the key legal right access in open source software, whereas patent is the dominant IPR form of protection open source biotechnology [20]. In terms of standards, "patentability" is a much higher standard than the "copyrightability" [88]. The cost of getting patents for the innovations in biotechnology can be exorbitant and time-consuming, compared to open source software that costs little and requires less time. Thus, patents can cause a setback in research and limit the experimentation by scientists or individual farmers. In addition, the research culture in open source software is different from open source biotechnology [26]. For example, the equipment used in biotechnology research is very expensive, when compared to software technology that requires a computer and a desk. Considering these factors, the open source approach would be more difficult to diffuse or move quickly in biology than in software.

Patent misuse through grant back mechanisms is another challenge in open source biotechnology [89]. As the technology advances, it may be difficult to keep the research tools and inventions within the confines of open source arena as technology becomes available to the wider research community. For example, in an attempt to seek rewards or compensation for any kind of improvement made to the technology, it may result in legal proceedings if the innovator involved feels that improvement made to the technology should attract greater rewards [89]. Under normal principles of patent law, inventors making novel improvements to the core technology are entitled to apply for patents as long as the requirements of patentability are met and the right improvements are followed. Therefore, the open source licencing agreement may be ignored by the inventor if there is greater reward. This can sometimes lead to shrouded or overlapping rights on research tools among multiple parties. The issue of the grant back mechanism as related to the open source licence may discourage collaboration that would facilitate ideas among young generations of scientists towards increasing creativity and better innovations. For example the grant back mechanism and BiOS viral licence have led to the rejection of BiOS licencing terms for the PIPRA project [90]. Moreover, in the context of the grant back approach, researchers who are interested in commercializing their research work could decide not to 
participate when confronted with the policy and process for commercialization.

\subsection{Agricultural biotechnology framework and policy implications for open source development}

\subsubsection{Proposed open source agricultural biotechnology framework}

Based on the analysis of the case studies and initiatives presented, an Open Source Biotechnology Framework (OSBF) shown in Fig. 2 is proposed as a possible solution for the adoption and promotion of agricultural biotechnology R\&D for sustainable development in developing countries. Using a similar principle to the open source software development process [6], the OSBF identifies agricultural biotechnology research and cooperation priorities which are highly dependent on technology for their effective implementation. As shown in Fig. 2, two developing countries (A and B) working on the same or similar biotech products (e.g. maize or sorghum) can leverage the principle of open source software development and openly collaborate in their R\&D activities. According to this framework, agricultural extension workers, research institutions, farmers, governments and other stakeholders can freely and collectively leverage the expertise of biotechnology developer and user bases. They can also benefit or learn from other biotechnology companies and vendors of the software who are willing to reveal and share their innovation, share their experiences and risks, associated with a particular agricultural product. This kind of intra/inter research and collaboration can even be extended to other countries or forms of international alliances where open source biotechnology research and innovation networks are already formed.
Benefits associated with this research and innovation network may include reducing or sharing costs and risks on: (1) using open source technologies and services, (2) exchanging staff and sharing of skills, (3) outsourcing essential services. However, as highlighted in Section 5.1, considerable training, re-training and education in the area of open source software development is essential for implementing this kind of framework. Cooperation and collaboration in areas such as open source awareness, policy harmonization across agricultural zones, farming communities and countries is fundamental for ensuring successful implementation and sustainability of this open source agricultural biotechnology framework.

\subsubsection{Policy implications for open source biotechnology}

5.2.2.1. Provision of adequate training. Training is the hallmark of effective and good management. Open source development requires adequate training in various aspects of FOSS in order to facilitate the introduction and growth of open source biotechnology in developing countries. It is necessary to establish a technical support and training policy for open source development, particularly in information and communication technology (ICT). ICT policies should be a part of the process and part of what is needed in the developing countries to promote and support open source. Policies adopted should support education and training at different levels. Due to the low level of ICT literacy in developing countries, strategies or policies designed for training should reflect basic skills (e.g. basic understanding in IT) and user-friendly methodology in any language of communication for the rural poor. For example, FOSS software used for AgriBazaar in connecting farmers and buyers in Malaysia was designed to serve the

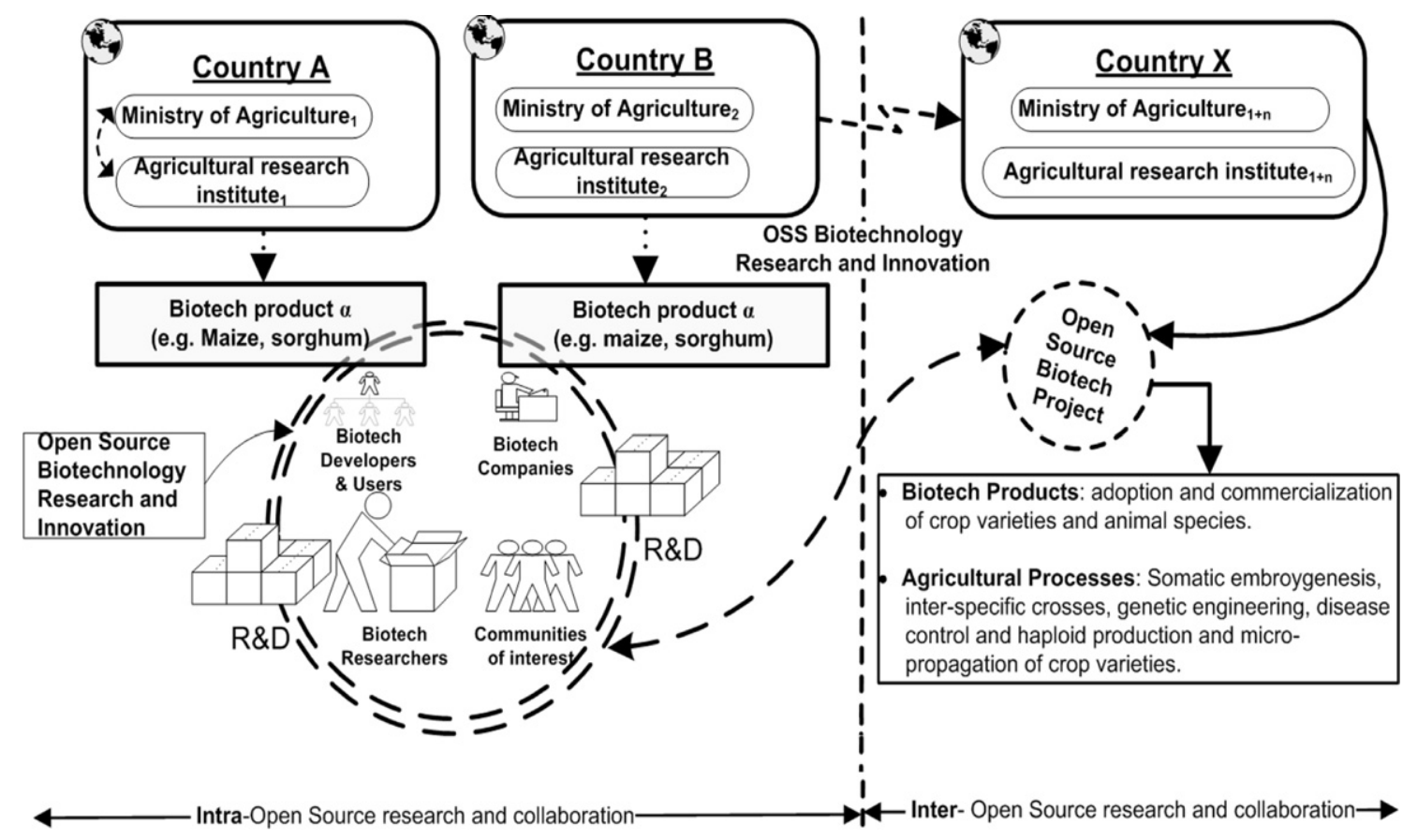

Fig. 2. Open source agricultural biotechnology R\&D framework. 
communities in various local languages [10]. This can facilitate the acceptance and participation among the targeted group at grass-roots levels. Moreover, training should be provided regularly in the course of the evaluation and adaptation process. Where necessary, retraining should be provided for sustainability and continuity.

5.2.2.2. Provision of adequate resources and facilities. Given the importance of open source biotechnology for the benefit of society, adequate resources would need to be committed to support open source development in developing countries. Apart from education and training, basic facilities such as telecommunication and electricity that will facilitate the application of open source in developing countries should be provided. In all of these, open source will require a big financial investment from the governments. Nonetheless, the cost of providing open source can be cheaper relative to proprietary software. For example, the migration of Ugandan University to open source resulted in significant cost reduction [91]. Other examples $[92,93]$ similarly show that open source is relatively inexpensive and easily adapted to local needs for various purposes. This is in sharp contrast to proprietary vendors that are globally profit-oriented with little connection to local needs [94]. Therefore, the government's policy should recognise the importance of FOSS and address the issues concerning the provision of right resources and allocation of budget for the development of open source project.

\subsubsection{Collaboration and network expansion. Collaborative} data sharing should be encouraged among the academic communities particularly in developed countries, as this will provide opportunities for researchers in developing countries to benefit. Most researchers in developing countries depend on scientific data and publication from developed countries to advance research in their areas. For example, developing countries have created successful science policies through a two-way contribution of international scientific exchange [95]. Therefore, collaborative data sharing, through open source is one approach to encourage scientific networking between scientists in developed and developing countries. Moreover, collaboration based on common tools where individual sharing of discoveries in biological innovation could be encouraged between universities and multinationals, paving the way for open source biotechnology.

5.2.2.4. Effective policy and legislation. The success of open source development requires that effective policy and legislation be developed and implemented in developing countries. Given the importance of political support, it can facilitate processes and increase the adoption rate if there is a high level of commitment. Therefore, government should formulate policies that encourage open source development and the policy should focus on the following areas:

- Support of ICT in education and the government sector at all levels;

- Enabling an environment for the accessibility of ICT by citizens, business and the government;
- Providing local professionals with adequate training and acquiring skills in relevant software development to remain viable in a competitive market;

- Identifying and prioritization areas of need such as local software development and IT industries;

- Adopting open standards for storage and preservation of data.

In addition, governments should work in conjunction with international agencies such as CBD, TRIPS and UPOV to create a friendly IPRs system that will encourage open source development for innovative technologies in developing countries. This can decentralize patented technologies and make them freely accessible to researchers in developing countries, particularly in agriculture biotechnology.

5.2.2.5. Flexible licencing policies. Open source licencing policy should be flexible enough to allow interested party to use innovation under the freedom of choice. For example, it should be practiced under the "four freedoms of choice": 1) Access without restriction; 2) Availability of source code; 3) Improve and add to the source code; 4) Redistribute the source code and software. The availability of genomic databases through bioinformatics provides flexibility for the terms chosen by the users. By contrast, biotechnology research does not usually provide an avenue for freedom of choice. Also, the current licencing policy of BiOS does not encourage freedom of choice due to the grant back mechanism [89]. BiOs allows users to refrain from the grant back improvement if kept as trade secrets where it prevents their improvement from being disclosed to another users. A recent report emphasises the fact that an enhanced open source model through a trade secret could offer a flexible policy agreement as proposed for the HapMap project [96]. In addition, a business-friendly licencing policy that will maximize the growth potential of open source biotechnology should be encouraged among the users. Encouraging flexible licencing policies under the open source approach could lead to the rapid development of research tools and increased economic benefits for users in developing countries.

\section{Conclusion}

The open source paradigm as applied to agricultural practices has the potential to compensate farmers for contributing to the growth of plant resources, and may serve as information resources for farming communities [87]. While this article discusses the complexity of IPRs in agricultural biotechnology, it also mentions the potential benefit and impact of open source in agricultural and biotechnology development. Addressing the three research questions posed in a systematic way provided insight into the development of open source biotechnology in developing countries. Most importantly, the analysis of specific case studies and initiatives led to the proposal of an Open Source Biotechnology Framework (OSBF) that can facilitate development of biotechnology R\&D, exchange of skills and ideas and collaboration among agricultural research institutes between different countries as well as policy 
recommendations to foster open source development in agriculture.

The adequate provision of basic infrastructure and financial resources will play a vital role in the adoption of open source biotechnology. Education forms the basis through which open source development can be promoted among the citizens, therefore quality education on ICT programs should be provided to encourage wide participation from the grass-root levels. The lack of political support due to a low level of awareness among the government officials on open source in developing countries can slow down open source development. Therefore, a concerted effort should be made to educate and encourage government officials in all relevant institutions. Given the impact of IPRs in creating a research environment for biotechnology, the IPRs system must be designed in a research-friendly way, particularly with regards to protection under law that will facilitate commercialization and technology transfer to developing countries. Added to this, institutional and legal frameworks must be established and encouraged to protect IPRs in developing countries so as to enhance the economic benefit of open source biotechnology products.

While this article has reviewed the existing literature with relevant information about the adoption of open source biotechnology in agricultural practices, not many initiatives or organisations are advocating for open source development for innovations that can enhance sustainable agricultural development. More effort is required from a variety of actors including the private sector, individuals, national governments and international agencies to support and promote open source biotechnology for sustainable agricultural development in developing countries. Moreover, a lot of work needs to be done in terms of further case study analysis to more fully assess the major areas where open source is being adopted, as well as the benefits and the constraints that are associated in open source adoption in developing countries.

Finally, if the introduction of open source biotechnology is to contribute to sustainable agriculture in developing countries, enabling environments must be put in place that include policy formulation and implementation for establishing, supporting and providing the capacity building and resources required to develop open source. Moreover, the attention and focus of open source development should not be restricted to one area but it should address other needs such as health and the environment. The opportunities offered by open source biotechnology can make a significant impact on sustainable agricultural development through free access to modern biotechnology techniques. Open source biotechnology is making slow but steady progress in agriculture, but many issues will have to be addressed to enjoy the benefits of this new innovation in developing countries. This article has raised important concerns that will lead to further debates among stakeholders including scientists and policymakers.

\section{Acknowledgement}

The first two authors would like to acknowledge the support of Japan Society for the Promotion of Science. The authors are grateful to the three anonymous reviewers for their comments on the article. Comments and suggestions from the editor, Charla Griffy-Brown, in improving the quality of the manuscript are gratefully acknowledged.

\section{References}

[1] WorldBanK. World development report, agriculture for development. Washington, DC: Office of the Publisher, the World Bank; 2008.

[2] James C. Global status of commercialized biotech/GM crops. The International Service for the Acquisition of Agri-biotech Applications (ISAAA); 2012. Brief 43.

[3] Adenle AA. Global capture of crop biotechnology in developing world over a decade. Journal of Genetic Engineering and Biotechnology 2011;9(2):83-95.

[4] Hemphill TA. Preemptive patenting, human genomics and the US biotechnology sector: balancing intellectual property rights with societal welfare. Technology in Society 2003;25:337-49.

[5] Frisio DG, Ferrazzi G, Ventura V, Vigani M. Public vs. private agbiotech research in the United States and European Union, 20022009. AgBioForum 2010;13(4):333-42.

[6] Gay J, Lessig L. Free software, free society: selected essays of Richard M. Stallman. Boston, MA: GNU Press, http://www.gnu.org/philosophy/ fsfs/rms-essays.pdf; 2002 [accessed April 2012].

[7] BiOS. Biological innovation for open society, http://www.bios.net/ daisy/bios/2518.html; 2005.

[8] Thorisson GA, Smith AV, Krishnan L, Stein LD. The international HapMap project web site. Genome Research 2005.

[9] Sowe SK. Free and open source software sustainability and innovation: lessons learnt from Sub-Saharan African. In: International conference on ICT for Africa, Nigeria, March 23-26, 2011; 2011. p. 199-203.

[10] Hoe NS. Breaking barriers: the potential of free and open source software for sustainable human development; a compilation of case studies from across the world. UNDP-APDIP; 2006

[11] Yin RK. Case study research: design and methods. In: Applied social research methods series. 3rd ed., vol. 5. Sage Publications; 2003.

[12] Denzin N. Sociological methods: a sourcebook. Aldine Transaction; 2006

[13] Stallman R. Free software, free society. Boston, MA: GNU Press; 2002.

[14] Voas J, Miller KW, Costello T. Free and open source software. IT Professional 2010;12(6):14-6.

[15] Raymond E. The cathedral and the bazaar: musings on linux and open source by an accidental revolutionary. Sebastopol, CA: O'Reilly Media; 1999.

[16] Weber S. The success of open source. Cambridge MA: Harvard University Press; 2004.

[17] Cassier M. New "enclosures" and the creation of new "common rights" in the genome and in software. Contemporary European History 2006;15(2):255-71.

[18] Hope J. Open source licensing. In: Krattiger A, Mahoney RT, Nelson L, et al., editors. Intellectual property management in health and agricultural innovation. A handbook of best practices. Oxford, U.K./Davis, U.S.A.: MIHR/PIPRA; 2007.

[19] FSF. Free Software Foundation. Free software definition, http:// www.gnu.org/philosophy/free-sw.html; 2008.

[20] Hope J. The open source revolution and biotechnology. Cambridge, MA: Harvard University Press; 2008.

[21] Wake S, Ridley RG. Virtual drug discovery and development for neglected diseases through public-private partnerships. Nature Review 2003:919.

[22] OBF. Open Bioinformatics Foundation. (www.open-bio.org).

[23] CAMBIA. Center for the Application of Molecular Biology to International Agriculture, http://www.cambia.org/daisy/cambia/about/ 3692/2518.html; 1991.

[24] Douthwaite B. Enabling innovation: a practical guide to understanding and fostering technical change. Boston, MA: Zed Books; 2002.

[25] Srinivas K. The case for biolinuxes: and other pro-commons innovations. In: Vasudevan R, Sundaram R, Bagchi J, Narula M, Lovink G, Sengupta S, editors. Sarai reader 2002: the cities of everyday life. New Delhi: Center for the Study of Developing Socities; 2002. p. 321-8.

[26] Hope J. Open source biotechnology. A thesis submitted for the degree of Doctor of Philosophy at The Australian National University. Available at: http://rsss.anu.edu.au/ janeth/ OpenSourceBiotechnology27July2005.pdf. 2004. 
[27] Blakeney M. Recent development in intellectual property and power in the private sector related to food and agriculture. Food Policy 2011;36(Suppl. 1):S109-13. Elsevier Ltd.

[28] Wright BD, Pardey PG, Koo B. Agricultural innovation: investments and incentives. In: Evenson R, Pingali P, editors. Handbook of agricultural economics, vol. 3; 2007. p. 2537-8.

[29] Safrin S. Treaties in collision? The biosafety protocol and the world trade organization agreements. The American Journal of International Law 2002;96:22.

[30] Moschini GC. Intellectual property rights and the world trade organization: retrospect and prospects, http://www.card.iastate. edu/faculty/profiles/giancarlo_moschini/moschini-trips-preprintoct-04.pdf; 2012 [accessed 28.05.2012].

[31] Van Overwalle G. Patent protection for plants. A comparison of American and European approaches. The Journal of Law and Technology 1999;39:143-94.

[32] Bocci R. Seed legislation and agrobiodiversity: conservation varieties. Journal of Agriculture and Environment for International Development 2009;103:31-49.

[33] Pardey PG, Alston JM, Chan-Kang C, Castello Magalhaes E, Vosti SA Assessing and attributing the benefits from varietal improvement research in Brazil. IFPRI Research Report. No. 136. Washington, DC: International Food Policy Research Insitutute; 2004.

[34] Cooper HD. The international treaty on plant genetic resources for food and agriculture. Review of European Community \& International Environmental Law 2002;11:116.

[35] Rai AK, Eisenberg RS. Bayh-Dole reform and the progress of biomedicine. Law \& Contemporary Problems 2003;66:289-300.

[36] de Janvry A, Graff G, Sadoulet E, Zilberman D. Technological change in agriculture and poverty reduction. Concept paper for WDR on Poverty and Development 2000/2001. Berkeley: University of California; 2000. p. 6-7.

[37] Jefferson R. Freely sharing innovation is the only way to face the future. Australian Leadership Retreat Special Report. The Australian August 31. 2007.

[38] Pray CE, Naseem A. Intellectual property rights on research tools: incentive or barriers to innovation? Case studies of rice genomics and plant transformation technologies. AgBioForum 2005;8:108-17.

[39] Parayil G. Mapping technological trajectories of the green revolution and the gene revolution from modernization to globalization. Research Policy 2003;32:971-90.

[40] Kryder DR, Kowalski SP, Krattiger AF. The intellectual and technica property components of pro-vitamin A rice (Golden Rice) a preliminary freedom-to-operate review. In. International service for the acquisition of agri-biotech applications (ISAAA) brief no. 20. ISAAA, Ithaca, NY; 2002.

[41] Isaac AG, Walter GP. On intellectual property rights: patents vs. free and open development, chapter 18 of Colombatto, Enrico, the Elgar companion to the economics of property rights. Aldershot, UK: Edward Elgar; 2004.

[42] Heller MA, Eisenberg RS. Can patents deter innovation? The anticommons in biomedical research. Science 1998;280:698-701.

[43] Rimmer M. Genentech and the stolen gene: patent law and pioneer inventions. Bio-Science Law Review 2003;5(6):198-211.

[44] Eisenberg RS. Why the gene patenting controversy persists. Academic Medicine 2002;77(12):1381-7.

[45] Arora A, Merges P. Specialised supply firms, property rights and firm boundaries. Industrial and Corporate Change 2004;13: 451-75.

[46] Bureth A, Penin J, Wolff S. Entrepreneurship in biotechnology: the case of four start-ups in the upper-Rhine biovalley. Working paper BETA, no.2006-21; 2006

[47] David PA. Can 'open science' be protected from the evolving regime of intellectual property rights protections. Journal of Theoretical and Institutional Economics 2004;160:1-26.

[48] Fisher WM. The impact of "terminator gene" technologies on developing countries. Report to the United Kingdom department for international development. December. http://www.law.harvard. edu/faculty/tfisher/terminator.html [accessed April 1999].

[49] ETCGroup. Ban terminator before it's too late. ETC News Release 5 April. 2002.

[50] Jefferson R. Transcending transgenics - are there 'babies' in the bathwater, or is that a dorsal fin? In: Pardey PG, editor. The future of food; biotechnology markets and policies in an international setting. Washington, DC: International Food Policy Research Institute; 2001. Ch.5.

[51] Pedleton $\mathrm{CN}$. The peculiar case of terminator technology: agricultural and intellectual property protection at the crossroads of the third green revolution. Biotechnology Law Report 2004;23 $1-29$.

[52] Eaton D, Van Tongeren F, Louwaars N, Visser B, Van der Meer I. Economic and policy aspects of 'terminator' technology. Biotechnology and Development Monitor 2002;49:19-22.

[53] Swason T, Goschl T. Genetic use restriction technologies (GURTs): impacts on developing countries. International Journal of Biotechnology $2000 ; 2(1 / 2 / 3)$.

[54] Goeschl T, Swanson T. The development impact of genetic use restriction technologies: a forecast based on the hybrid crop experience. Environment and Development Economics 2003;8:149-65.

[55] Martin MA. Biotechnology, gene flow, and intellectual property rights: an agricultural summit. In: Proceedings of a conference held the anticommons in biomedical research September 13, in Indianapolis, Indiana; 2002

[56] Giovannetti M. The ecological risks of transgenic plants. Rivista Di Biologia 2003;96:207-23.

[57] Daniell H. Molecular strategies for gene containments in transgenic crops. Nature Biotechnology 2002;20:581-6.

[58] Shoemaker R. Economics issues in agricultural biotechnology. Agricultural Information Bulletin No.762. Washington DC: Economic Research Service, United States Department of Agriculture; 2001

[59] Thies JE, Devare M. An ecological assessment of transgenic crops. Journal of Developmental Studies 2007;43:97-129.

[60] Steinbrecher RA. V-GURTs (terminator): can it be effective as a biological containment tool? EcoNexus. CoP-MoP2, http://www. econexus.info/sites/econexus/files/ENx_V-GURTs_brief_2005.pdf; 2005 [accessed 30.05.2012].

[61] RF Rockefeller Foundation. "Food gains for the world's poor are being threatened by furor over genetically modified (GM) foods". Press release, Rockefeller Foundation Washington DC. 1999.

[62] CGIAR. Shaping the CGIAR's future: summary of proceedings and decisions. Consultative Group on International Agricultura Research (CGIAR) International Center Week, October 26-30. Washington, DC: CGIAR Secretariat; 1998.

[63] OECD. Organisation for Economic Co-operation and Development (OECD). Intellectual property and competition policy in the biotechnology industry. June, Policy Brief; 2005.

[64] Thomas D, Hunt A. Open source ecosystems. IEEE Software 2004; 21(4):89-91.

[65] Fitzgerald B. Open source software adoption: anatomy of success and failure. International Journal of Open Source Software \& Processes 2009:1-23.

[66] Wright BD. Public germplasm development at a crossroad: biotechnology and intellectual property. California Agriculture 1998;56:8-13.

[67] Erbisch FH, Maredia KM. Intellectual property rights in agricultural biotechnology. CAB International; 2004

[68] Hoekman BM, Maskus KE, Saggi K. Transfer of technology to developing countries: unilateral and multilateral policy options. Institute of Behavioral Science (IBS). University of Colorado; 2004. Working Paper.

[69] Fenton GM, Chi-Ham C, Boettiger S. Freedom to operate: the law firms approach and role. In: Krattiger A, Mahoney RT, Nelsen L, Thomson JA, Bennett AB, Satyanarayana K, et al., editors. Intellectual property management in health and agricultural innovation: a handbook of best practices. Oxford, U.K./Davis, U.S.A: MIHR/PIPRA, http://www. iphandbook.org/handbook/chPDFs/ch14/ipHandbook-Ch\%2014\% 2004\%20Fenton-Chi-Ham-Boettiger\%20FTO\%20and\%20Law\%20Firm \%20Roles.pdf; 2007 [accessed April 2012].

[70] Pardey PG, Wright BD, Nottenburg C, Binenbaum E, Zambrano P. Intellectual property and developing countries: freedom to operate in agricultural biotechnology. Brief 3. Biotechnology and Genetics Resource Policies; 2003.

[71] USAID. The U.S Agency for International Development (USAID). Selecting mobile ICT Devices for agriculture services and application in Sub-Saharan Africa. Briefing Paper; 2011.

[72] Pickernell DG, Christie MJ, Rowe PA, Thomas BC, Putterill LG, Griffith JL. Farmers in Wales: marketing the network? British Food Journal 2004:106:194-210.

[73] Schechter M. Innovation of the week: open source software for agriculture and Nutrition. State of the World 2011: innovations that nourish the planet. http://blogs.worldwatch.org/ nourishingtheplanet/innovation-of-the-week-open-sourcesoftware-for-agriculture-and-nutrition/[accessed April 2011].

[74] FSU. FrontlineSMS Users (FSU). Learning more about FrontlineSMS users: results from our first ever survey, http://www.frontlinesms. com/2011/04/13/learning-more-about-frontlinesms-users-resultsfrom-our-first-ever-survey/; 2012 [accessed 28.05.2012]. 
[75] Qiang CZ, Kuek SC, Dymond A, Esselaar S. Mobile application for agriculture and rural development. ICT sector unit. Washinghton DC: The World Bank; 2011.

[76] Rannu R, Saksing S, Mahlakõiv T. The mobile government: 2010 and beyond. The white paper. European Union Regional Development Fund; 2010.

[77] Balasubramanian D, Lie R, Grard P. ICT and agriculture in India: a perspective from the case study based on the oscar project (open source simple computer for agriculture in rural area). NETCOM 2009;23(3/4):281-92.

[78] ETA. eTransform Africa. Agriculture sector study sector assessment and opportunities for ICT, http://etransformafrica.org/sites/default/ files/Readers-Digest-Agriculture.pdf; 2012 [accessed April 2012].

[79] Lander ES, Lai EH, Nickerson DA, Abecasis GR, Altshuler D, Bentley DR, et al. The international HapMap project. Nature 2003; 426:789-96.

[80] BiOS. BiOS (Biological Innovation for Open Society). http://www. bios.net/daisy/bios/2518.html. [accessed April 2012].

[81] PIPRA. PIPRA (Public Intellectual Property Resource for Agriculture). http://www.pipra.org/about/[accessed April 2012].

[82] Boadi RY, Bokanga M. The African agricultural technology foundation approach to IP management. In: Krattiger A, Mahoney RT, Nelson L, et al., editors. Intellectual property management in health and agricultural innovation: a handbook of best practices. Oxford, U.K: MIHR; 2007.

[83] Boetigger S, Wright BD. Open source in biotechnology: open questions. Innovations Case Discussion: CAMBIA-BiOS; 2006.

[84] Thomas Z. Open source agricultural biotechnology. Current Science 2005;88:1212-3.

[85] Atkinson RC, Beachy RN, Conway G, Cordova FA, Fox MA, Holbrook KA, et al. Intellectual property rights. Public sector collaboration for agricultural IP management. Science 2003;301: 174-5.

[86] Penin J, Wack J. Research tool patents and free-libre biotechnology: a suggested unified framework. Research Policy 2008;37:1909-21.

[87] Beck RH. Farmers' rights and open source licencing. Express; 2010.

[88] Lemley MA, O’Brien DW. Encouraging software reuse. Stanford Law Review 1997;49:225.

[89] Feldman R. The open source biotechnology movements: is it patent misuse? Minnesota Journal of Law Science \& Technology 2004;6: 118-67.

[90] PIPRA. PIPRA's evaluation of the BIOS license. PIPRA's summer 2006 quarter newsletter, issue 5, http://www.pipra.org/en/documents/ PIPRA-Newsletter-Issue5.pdf; 2006.

[91] Bruggink M. Open source in Africa: towards informed decisionmaking. IICD Research Brief-No 7; 2003.

[92] Weber S. Open source software in developing economies. Berkeley: University of California, http://webarchive.ssrc.org/programs/itic/ publications/ITST_materials/webernote2.pdf; 2012 [accessed 30.05. 2012].

[93] Ariyabandu R, Zengpei X. Free open source software for disaster management: a case study of Sahana disaster management system of Sri Lanka. ESCAP Technical Paper; 2009.

[94] Ghosh RA, Schmidt P. Open source and open standards: a new Frontier for economic development?; 2006. Policy Brief. No 1.

[95] Forero-Pineda C. Convergence of research processes, big and small scientific communities. In. IIASA workshop, Laxenburg, Austria; May 1997.

[96] Gitter DM. Resolving the open source paradox in biotechnology: a proposal for a revised open source policy for publicly funded genomic databases. Computer Law \& Security Report 2008;24: $529-39$
Dr. Ademola A. Adenle holds a M.Sc in Genetic Manipulation from University of Sussex, UK and a Ph.D. from University of Nottingham, UK. Dr. Adenle has published in several peer-reviewed international journals including book chapters. He has won prestigious awards including the best student prize for his PhD research presentation at the British Toxicology Society's Annual Congress in Surrey, UK. He first authored a reviewed paper on spaceflight which attracted interest from UK and US media respectively. His current research at the United Nations UniversityInstitute of Advanced Studies (UNU-IAS) is based on the role of biotechnology in sustainable agriculture and climate change mitigation/adaption in developing countries, particularly in Africa. He has visited and looked into the procedures leading to the development of biosafety regulatory frameworks across different African countries including Ghana, Nigeria, South Africa, Kenya, Egypt and Tunisia. He is also a visiting scholar at the National Graduate Institute for Policy Studies (GRIPS), Tokyo, Japan.

Dr. Sulayman K. Sowe holds a PhD (summa cum laude) in Computer Science from Aristotle University, Greece (2007), MSc and Advanced Diploma in Computer Science from Sichuan University, China (1997), BEd in Science Education from University of Bristol, UK (1991), and a Higher Teachers Certificate (HTC) from Gambia College, the Gambia (1988). Dr. Sowe previously worked as a senior researcher at United Nations University of Maastricht Economic and social Research and training centre on Innovation and Technology (UNU-MERIT), Netherlands, applying qualitative and quantitative data analysis techniques to identify patterns of Open Source Software innovation and technological sustainability in firms and communities. He is currently pursuing research funded by the Japan Society for the Promotion of Science (JSPS), at the United Nations University Institute of Advanced Studies (UNU-IAS) in Yokohama, Japan. He is also a visiting scholar at the National Graduate Institute for Policy Studies (GRIPS), Tokyo, Japan.

Professor Govindan Parayil, an Indian national, joined the United Nations University (UNU) as Vice-Rector in August 2008, and as Director of United Nations University Institute of Advanced Studies in January 2009. He currently serves as both Director of UNU-IAS and Vice-Rector of UNU. He holds a Bachelor of Science degree (Electrical Engineering) from the University of Calicut (India), a Master of Science degree (Science, Technology and Values) from Rensselaer Polytechnic Institute (USA), a Master of Arts degree (Development Economics) from American University (USA), and a Ph.D. in Science and Technology Studies from Virginia Polytechnic Institute and State University (USA). He authored Conceptualizing Technological Change (1999) and edited Kerala: The Development Experience (2000) and Political Economy and Information Capitalism in India (2006), and has written numerous book chapters and articles in international journals. His newest book (co-edited with A.P. D'Costa) on The New Asian Innovation Dynamics: China and India in Perspective was published in January 2009. He is active in research and advocacy work in science, technology and innovation for sustainable societies

Dr. Obijiofor Aginam was educated in Nigeria and Canada. He holds a Bachelor of Laws (magna cum laude) from University of Nigeria; Master of Laws from Queen's University at Kingston, Canada, and a Ph.D. from the University of British Columbia, Canada. Before joining United Nations University (UNU), he held a tenured academic position as Associate Professor of Law at Carleton University, Ottawa, Canada where he taught and researched emerging global issues that cut across globalization, global governance of health and environmental issues, South-North relations, international organizations, and Third World Approaches to International Law (TWAIL). 